\title{
CORRELATION BETWEEN INTERAURAL TIME AND INTENSITY DIFFERENCE IN THE SOUND LATERALIZATION
}

\author{
By \\ YASUO TAKEO \\ From the Department of Oto-rhino-laryngology Faculty of Medicine, University of Tokyo
}

(Director: Prof. I. Kirikae)

It has been said that interaural time and instensity difference play a greatest role in the directional hearing.

An apparatus ideally suited in examining the correlation of these two factors which can produce any interaural time differences without changing interaural intensity difference was made.

In this report, the mechanism of the apparatus and the results obtained were explained.

In the complex sounds (music, speech and white noise), the just noticeable difference in time was smaller than in other sounds (continuous and interrupted pure tones), and it was too large to be esti. mated in 2,000 cps pure tone.

By the centering technique, we examined the interaction between interaural time and intensity difference and compared time vs, intensity ratios (At/Ai) of octaveband-noises.

It was found that the time vs. intensity ratio was effected by both intensity and frequency of test tone, and that bilaterally lateralized two sound images were recognized as Banister and others reported when the test tone was too loud or inte. raural time difference was too large.

Time vs. intensity ratio was the smallest in the $600 \sim 850 \mathrm{cps}$ band-noise (SL. $40 \mathrm{~dB}$ ).

When test tone was interrupted, the results were different from that of continuous test tone, as follows;

1) A sound image located more clearly.

2) Even $2,000 \mathrm{cps}$ pure tone yields a clear sound image.

3) Time vs. intensity ratios were smaller in general.

4) Two sound images which lateralized to each ear in continuous test tones disappeared and a single clear image was heard.

\section{音の聴えの方向感に関する研究}

\section{その 1 方向感に和ける時間差と強度差の関係}

\section{東京大学医学部耳鼻咽喉科学教室（主任：切替一郎教授）}

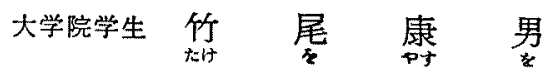

目次

\section{门鉝言 \\ II 実駼装䁂 \\ 四実駼方法 \\ W 実験成㴶}

i. 音の種類と方向感 ii. Time vs. Intensity

iii. 㭘查音の切断が方向感化及注す效果

V 総括並びに考按

i. 実験装置の特長

ii. 実䮖方法と乞の原理に関する考按

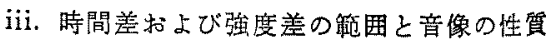


iv. Time vs. Intensity と強さとの関係

v. Time vs. Intensity と周波数との関係

vi. 検查音切断による Time vs. Intensity への 影響

V1 結 論
VII
芴考文献

\section{I 緒言}

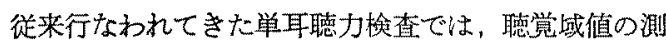
定及び伝音性難聴字指摘することはできるが，感音性難 聴については, いわゆる後寀路性難聴の鑑別，更にはそ の病巣部位の診断は不可能である。そのために簡明にし て確実な病栄診断法の必要が痛感されてきた.

すでに Fowler による音の平衡検查法, Békésy 型 自記オージオメトリー，語音明膫度検查，騒音聴力検查 法などの諸法が工夫され，かなり病巣揨䉼の可能性が出 てきたけれよ゙す，まだ十分とはいえない。

このよ5に単耳聴力検査法のるつ多くの問題点が認識 されるに至り，ここに新たに両耳聴力検查法の必要性が 晿えられ、それに向つての期待は次第に高まりつつあ Љ.

两耳聴力検植法の一つである両耳融合検查は，すでに Jerger 1), Groen 2), Matzker ${ }^{3)}$, Bocca 4) 等にみるよう にかなりの研究が行なわれ，実地に供されているが，む ら一つの方向感検查による方法は未だ惑問点が多く，実 地に応用されるには更めて根本から検討しなおすことが 必要と思われる、すなわら，今迄炕発表された方向感の 成立機序に関寸る諸学説には一長一碏があつて，これで すべての現象が解釈できるところまで到つていない。 また，今までに発表された中枢性難聴と思われる患者に ついての方向感検查の 成績 (Matzker ${ }^{5)}$, Jonkees ${ }^{6}$ ),

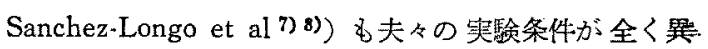
り，使用機峨も複雑であるため，こ叔を実地に応用する ことは扔か，その臨床成績を一率に評価し綜合するこ。 とは未だ困難な段階にある。

そこで我々は，方向感検查法を病栄婷断沈応用するこ とを究極の目的として新たに榆查機械を試作した，そし て先卞本装置を用いて方向感成立機序に最も重要な役割! を演す五雨耳間の音の強度盖上，音源から雨耳到達す るに要寸る時間差を夫々単独に，またはそれらの相望閶 係について検査し，方向感成立に拈ける夫ヶの要素の重 要性を检討せんとした。

\section{II 実験装置}

万向感成立機序を検討するには，両耳に入る音の時間 差之強度差を夫々別個に操作できるような機栈を必要と する，そのため我々は I. T.D. (interaural time difference）調整装置を案出し，検查音の強度差を变えるこ となく，時間差のみる自由に变えることのできる機械を 試作し，方向感に打ける時間差と強度差つ役割を夫々単 独に検查できるようにした。

試作した検查機㧴の機搆引 block-diagram として示

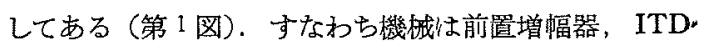
調整装置, mixer, 主增幅器より成り，これに䍚波器，

騒音発生装置, electroswitch が附属する.

検査音としては純音，騒音，話声，湶音を使用し，こ れらをオージオメーター、テープレコーダー,レコード プレーナー、ラジオ，騒音発生装置より導いたが，濾波 器や electroswitch を介することによつて周波数または 時間因子を歪めて使用できる。これらの音はうITD調整 装埴を介するか，あるい㥀接に主增幅器に尊き，さら に mixer を介するか否かによつて2。種の音を左右夫か

第 1 图 Block-diagram

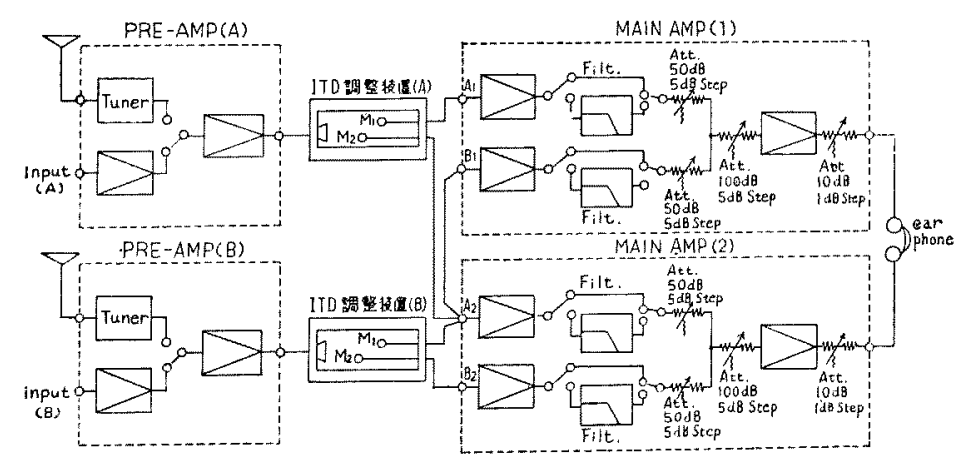


の耳に別個に，または一側耳に重礼て入れることができ る。李た本装置によつて検查音の時間差を自由に変えて 聞かせることがでさる。

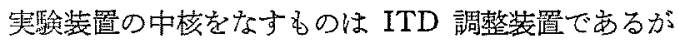
(第2 図)，その原理は定常波ができないらに工夫した 音響箱内において，2 個の移陲マイクロホンと定位のス ピーカ一の距離を变えて，マイクロホンへの到達時間差 をつくることにより，強さを变亮ることなく時間差のみ を变化できるようにしてある。特性は第3図の如く200

第 2 図 I.T.D. 調整装置

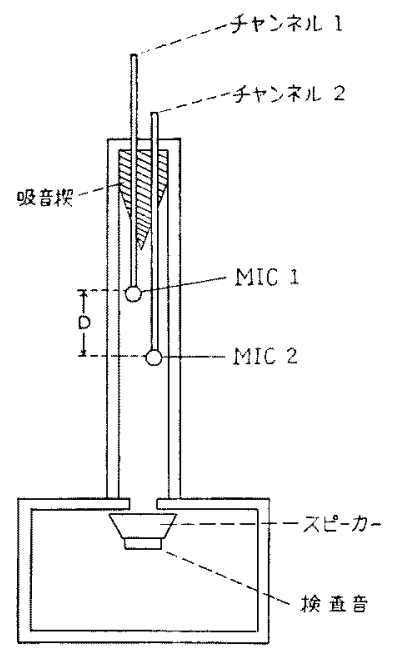

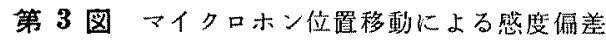
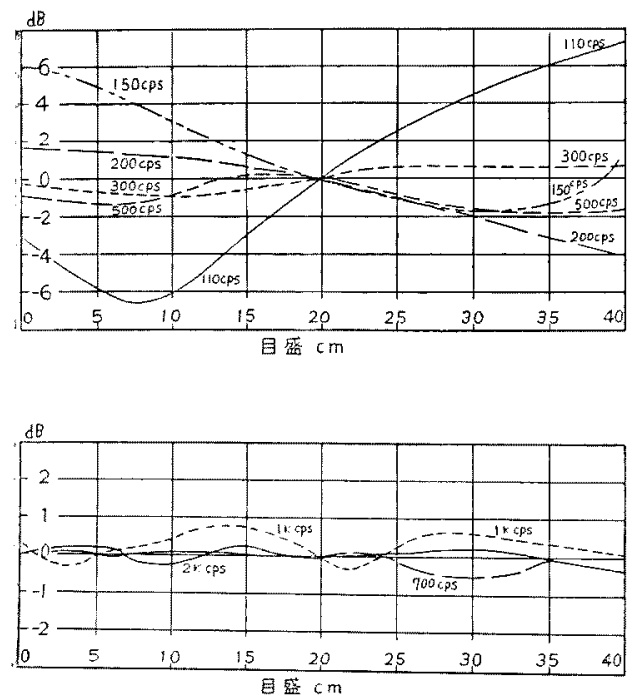

cps から 500cps までの低音域では，マイク移動よるる 音の大きさの変化は $\pm 2 \mathrm{~dB}$ 以内であり，700 cps から $2000 \mathrm{cps}$ 采での高音域では $\pm 1 \mathrm{~dB}$ である. 従って出力 が常に一定であるようにVUメーターで監視し，微調 整して実験すれば，200cps〜2000cps 間の検查音ではマ イク移動による音圧の差を無視して検査を実施すること ができた、マイクの移動は $1 \mathrm{~mm}$ 単位の目盛りで上下 夫タに $20 \mathrm{~cm}$ づっ, 都合 0 〜0 $\mathrm{cm}$ の時間差をつくるこ とができる。

上記の試作機械は万向感，両耳融合効果，歪語音明賸 度検査を併せて試験することが可能で，更に自記オーシ オメーターにも接続できる極めて応用範囲の広いもので あるが，今回行なつた实験ではその一部を使用するに止 めた（第 4 図）.

第 4 図 Block-diagram

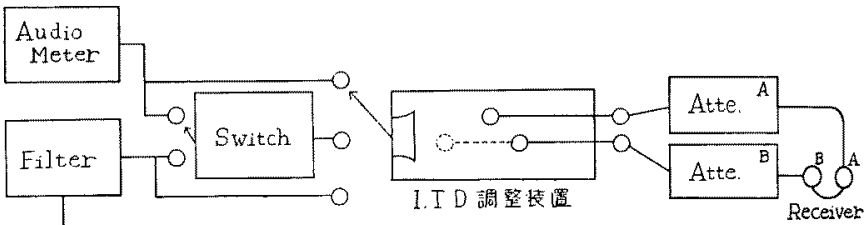

\section{III 実験方法}

被験者は，この種の dichotic（すなわち，レシーバ に上る方向覚認知）の垁験儿熟練した聴力正常者 4 名を 選び，4名の平均值をるつて測定值としたが，倜人に上 つて正中軸の偏倚があることを桬念してレシーバーを左 右交換して再検するなど慎重を期した。

音の大きさの規定はすべて感覚レペル統一した，检 查音の周波数は機械の都合から $300 \mathrm{cps}$ から $2000 \mathrm{cps}$ 亦 での音を使用した。

なお，この種の実験には疲労及び順応現象户心理作用 が強く影響するので，疲労，順応及び暗示がないように 極力注意を払つた。

1）先ず音の種類による方向感の差を調べるため， オ ージオメーターからのの純音 (500cps, $1000 \mathrm{cps}, 2000 \mathrm{cps}$ 及びそれらの切断音)，ラジオからの楽音，語音明贆度 桧查用レコードからの言語音，騷音発生装置からの白駩 音を，初めは時間差及び強度差なしで聞かせて音像方正 中にむすぶことを確めたのち，ITD 調整装置により1,5 $\mathrm{cm}, 3 \mathrm{~cm}, 5 \mathrm{~cm}, 10 \mathrm{~cm}, 20 \mathrm{~cm}$ の時間差を与文て音像の 
移動が認知されるかどうかを答えさせた．以上の 5 点で 音像の移動が認められ始場合は $30 \mathrm{~cm}$ まで連続的汇時 間差を与えて检查した。

2) 次いでオージオメーターからの純音 (500cps, 1000 cps）と腹波器によつて半オクターブ幅の 周波数幅にし た band-noise を直接に，または electroswitch によつ て切断しながら，ITD調整装置に導き，予め時間差 $(5 \mathrm{~cm}, 10 \mathrm{~cm}, 15 \mathrm{~cm}, 21 \mathrm{~cm})$ を与光ることによつて偏倚 させた音像を正中に戻すには，遅れて到達した方の音， すなわち音像と反対側に入る音の強さをいくら增強して やればよいかを測定した。これが Time vs. Intensity (以後 T vs I と略す) と呼ばれるものである.

3）次に検查音を electroswitch で切断することによ る T vs I への影響を調ベた。

検查音切断のために用いた electroswitch は2チヤン ネル両耳検査用で，両耳に交互に切断音が聞光るように なつている. 切断条件仗 duty cycle が50\%で，repe- tition period は $25,50,100,250,500,1000 \mathrm{~m} \sec \omega 6$ 段階に分け, rise and decay time は $1 \mathrm{msec} 225 \mathrm{msec}$ の2つとした．従つて切断音の波型は梯形をなしてい る. 検查音の種類は純音と band-noise の2 種を使用し たが，周波数幅性持続音の時の $\mathrm{T}$ vs I と比較する意 味で同じく半オクターブ幅とした。. 純音及び band-noise を上記条件で切断したが原音の感じは損ねていない．

被蛤者に時間差及び强度差のない音を聞かせて音像が 正中にできることを確めたのち，10cm の時間差をつく つて一側へ音像を偏倚させ，この音像を正中位に戻すに 必要な後澾音の增強分を $\mathrm{dB}$ で院んだ. 持続音の代りに 切断音を使用した以外は，持続音による T v I 湘定の 時と全く同樣の実験を行つた。

\section{IV 实験成精}

i. 検查音の種類と方向感

音の種類によって方向感の良いむのと㤠いものとがあ る.それを比較したのが第 5 图である、すなわち、集

第 5 図

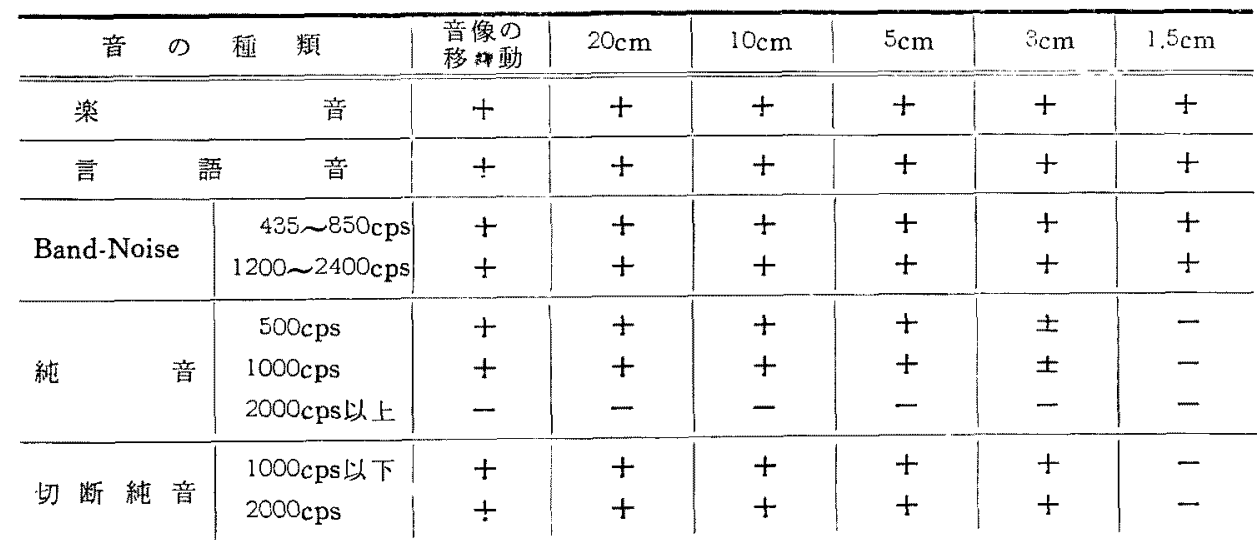

音, 言語音, band-noise は僅か $1.5 \mathrm{~cm}$ の時間差で音像 の移動が認知され，きかめて方向感が鋭敏であることが 判る. band-noise の高音域のものと低音域のものとの 差はこの実駼では㷵められなかつた。

次いで純音を適当に切断したものでは $1.5 \mathrm{~cm}$ の時間 差では音像の移動が認められず，3cm の時間差で初め て音像移動が認知された。 $500 \mathrm{cps}, 1000 \mathrm{cps}$ ，の純音では $5 \mathrm{~cm}$ の時間差を要し, $2000 \mathrm{cps}$ では時間差を $21 \mathrm{~cm}$ 越えて $30 \mathrm{~cm}$ 中で大きくしても音像移動を感じないば かりか音像を結ぶかどうかも確かでなかつた．2000cps の純音を除いて他の検查音では音像が明確に認められ， しかむ楽音，言語音，band-noise では音像が焦明で眭 間差の変化につれて明確な斬跡を描いた。 $2000 \mathrm{cps}$ の䌅 音の場合には音が雨側に聞こえ，音が頭の中一杯に拉が り、時間差の桨化が判らないため，この周波数の純意は 晏信を結ばないと断定した

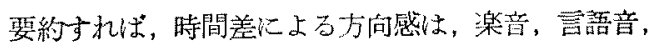
騷音の如き複雑音ほど明璄であり，純音が最も不明暸で ある。しかる2000 cps の純音では音像老結ばない、し かし，万向感が不明膫な純音でもこれを切断すれ枋方向 感が明瞭になることが知られた。

ii. Time vs Intensity 
第 6 図

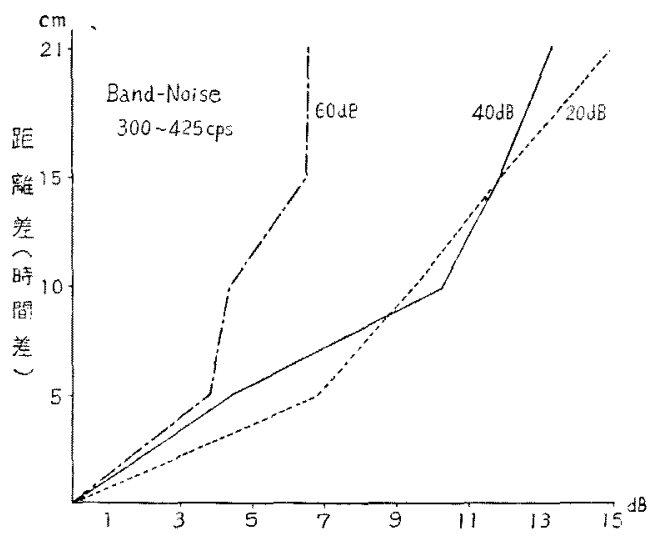

第 7 図

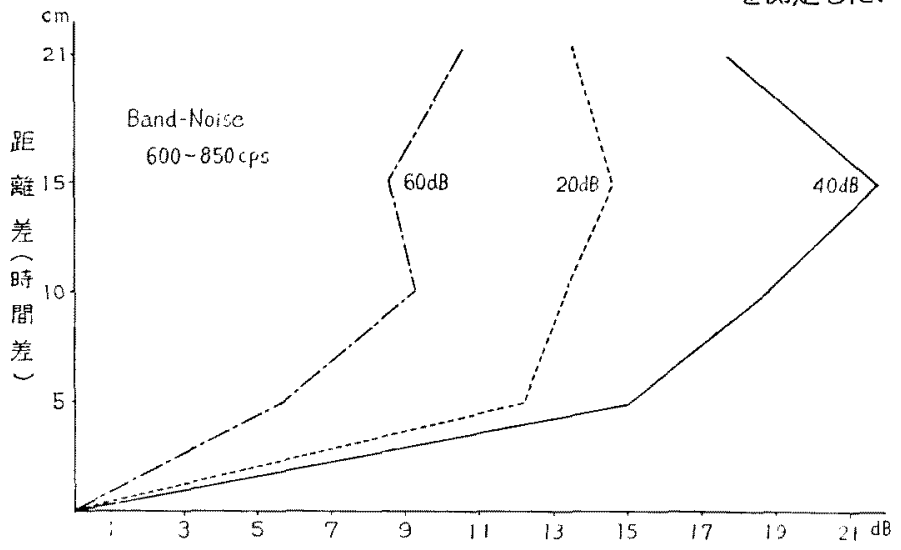

第 9 図

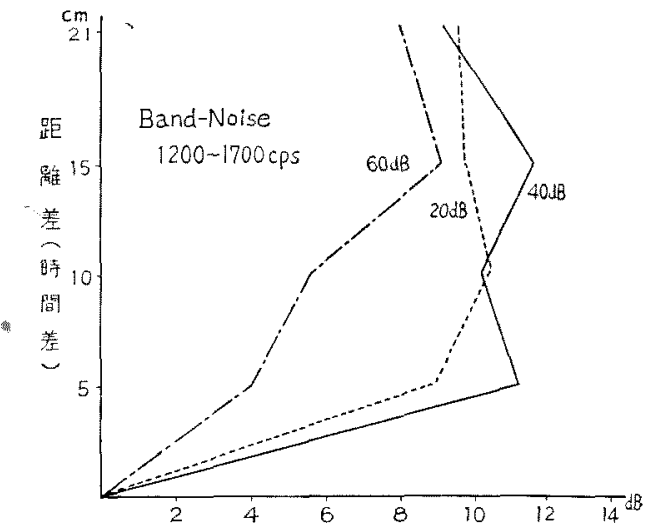

半オクターブ幅に濾波した band-noise で T vs. 1 を測定した. 300〜425cps, 600〜850cps, 850 1200 cps, $1200 \sim 1700 \mathrm{cps} 94 \supset 0$ band-noise $K$ ついての結果をグラフに示したのが第 6，7，8，9図である.予め与充ておいた 時間差を縦軸にとり，その時間差により て偏倚した音像を正中に戾すに必要とし た後達音の增強分を $\mathrm{dB}$ で横䡛に示し てある。

グラフの勾配をみると，600〜850cps が最も緩かで，検查音 $40 \mathrm{db}$ ，時間差 15 $\mathrm{cm}$ の場合の後達音增強 $\mathrm{dB}$ は $20 \mathrm{db}$ 以 上を要している。300 425cps, 850 $1200 \mathrm{cps}, 1200 \sim 1700 \mathrm{cps} \sigma$ band-noise の闪配がこれに次ぎ，検查音の強さ 40

第 8 図

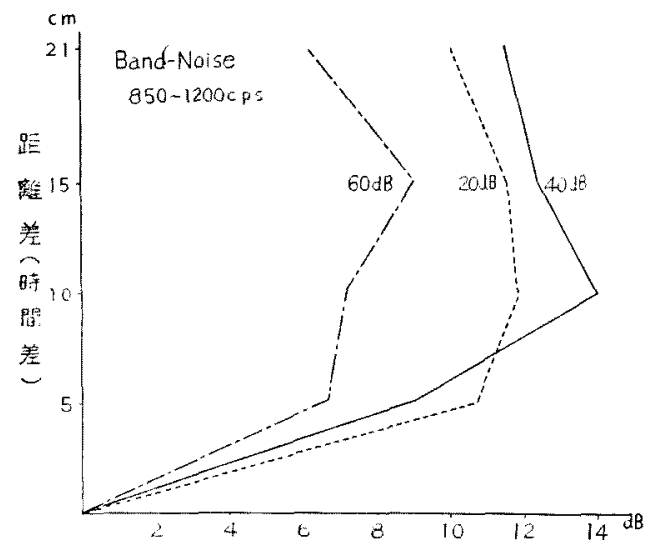

$\mathrm{db}$ ，時間差 $15 \mathrm{~cm}$ で約 $12 \mathrm{~dB}$ の後達音增強を必要とす ๖.

曲線の形は 850〜1200cps, 1200〜1700 cps で極めて類 似を示し，600 850 cps のグラフと共に $15 \mathrm{~cm}$ 以上の 時間差では却つて時間差の占める役割か゚减して曲線忺 㕛を生じているのが目立つ. 300〜 425cps の低音におい てこの田名見られないのと著しい奶照を示している。

检查音の強さによる違い各周波数幅について比蔽し てみると、いずれの band-noise に拪いて 60dBの曲 線が著しく立つていて，時間差の占める役割が小で る. 大差はないが $40 \mathrm{~dB}, 20 \mathrm{~dB}$ の順に曲線の勾貶が

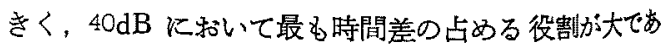
つた.すなわら，時間差による方向感は 600〜850cps のあたりが最も良く，強さも $40 \mathrm{~dB}$ が最む良い，方向感 
成立には检查音の周波数と強さが大きく関係することが 明確となつた。

iii. 検查音の切断が方向感に及ぼす効果

electroswitch に上つて検査音を適当化切断した实験 では，一般に方向感が著明に良くなる現象がみられた。

しかし，600 850cps の band-noise (40dB) 飞おける が如く非切断音でも方向感が良かつたものでは，切断し てもその効果が殆んど見られなかつた。すなわち。

Tívs I のグラフによつて大きさ $40 \mathrm{~dB}$ の $1000 \mathrm{cps}$ 純音について切断効果をみると(符 10 図)，非切断音で

\section{第 10 图}

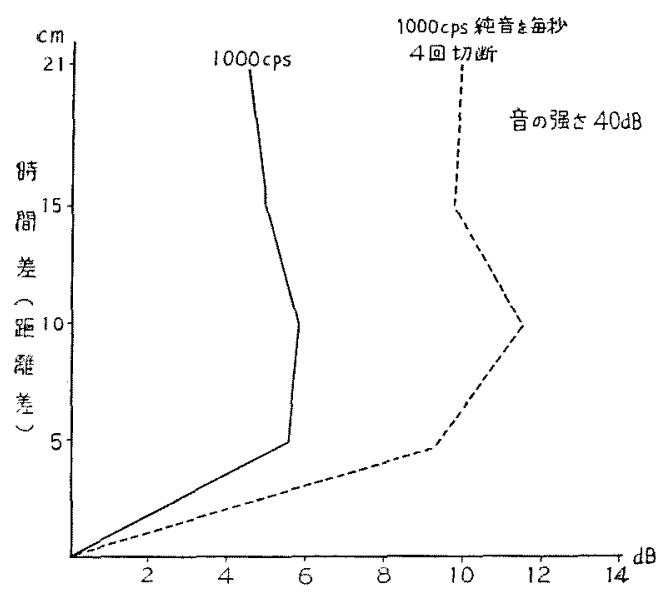

第 11 図

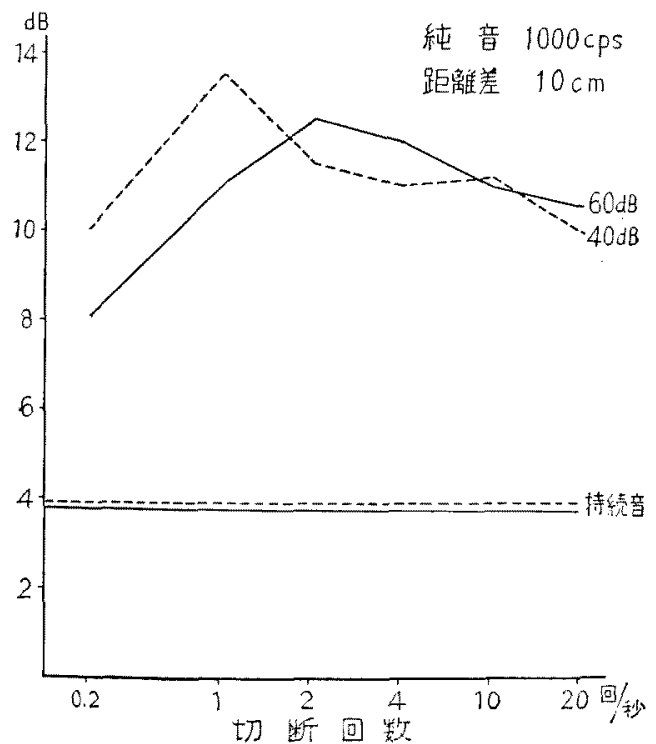

は後達音を5〜6dB たけ増強すればよいのに，毎秒4回 切断すると 10〜11dB の增強を，必要とする，各検查音 について時間差を $10 \mathrm{~cm}$ に固定した場合の $\mathrm{T}$ vs I $と$ 切断との関係を示したのが第 $11 １ 2 １ 3 ， 14$ 図である，

第 12 図

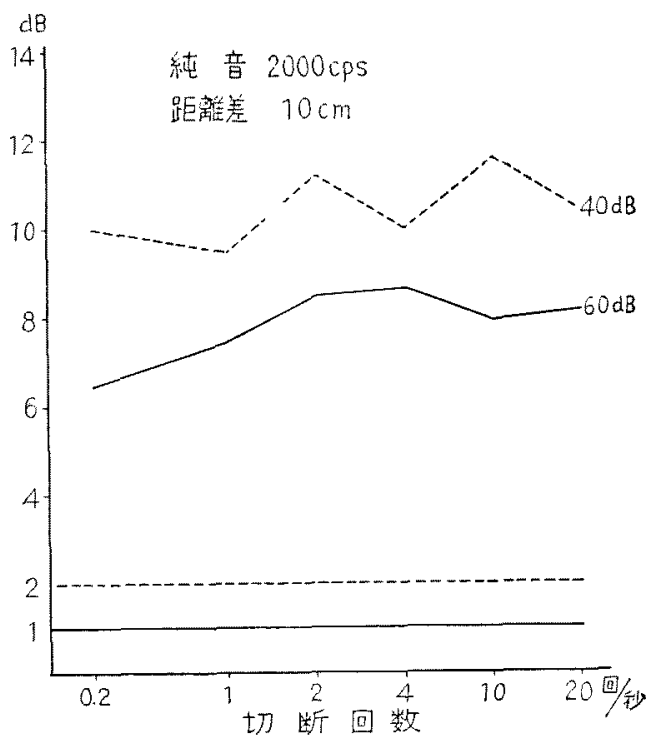

第113 図

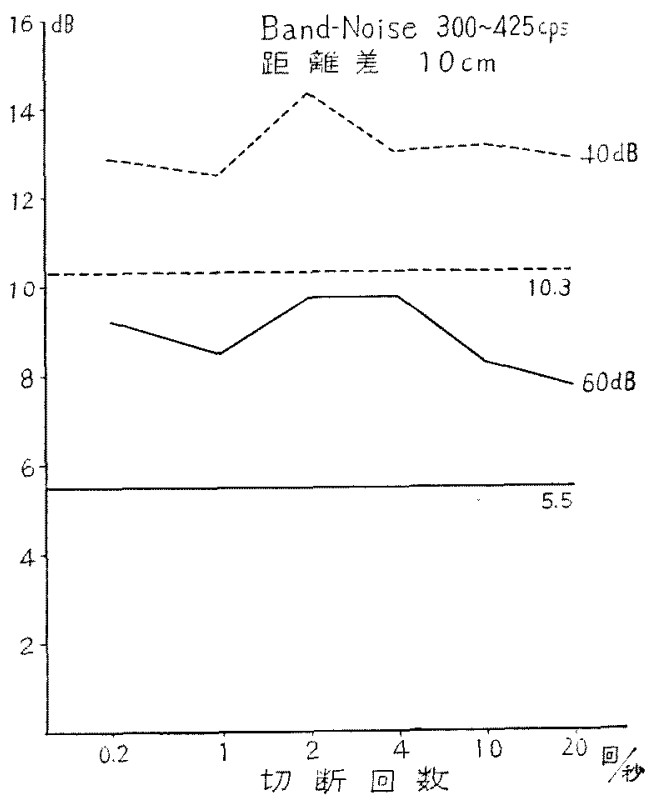




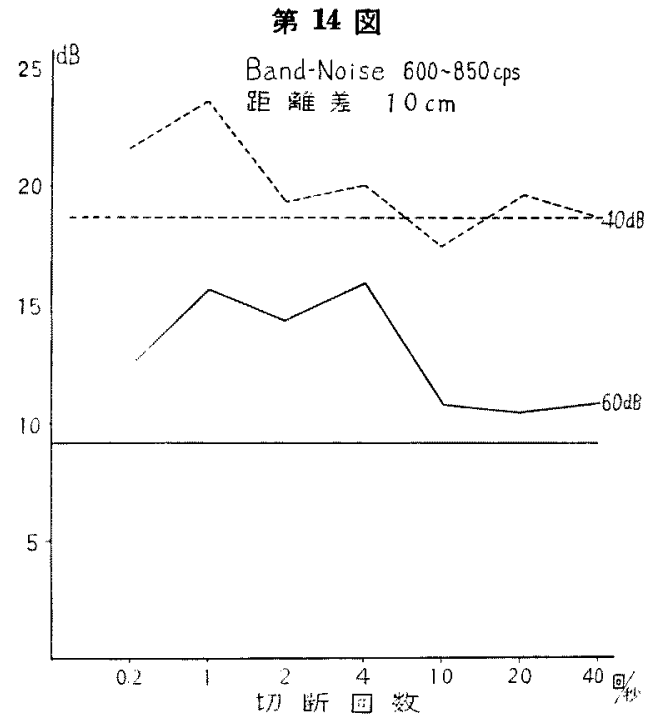

これらのグラフは rise and decay time が $1 \mathrm{~m} \mathrm{sec} の$ 場合のものを示してあるが，25 m sec の場合と有意の差 は㤎められなかつた。

$1000 \mathrm{cps}$ 純音では非切断音の場合の後達音增強分が $4 \mathrm{~dB}$ であるが，切断すると 10〜12dB となつた。 2000 cps 純音の場合む切断しない時には音像がはつきりれ ず，T vs I 洞定が殆んど不可能であつたのに，切断す ると8〜11dB の後達音堌强を必要とした，純音のみな 政 $300 \sim 425 \mathrm{cps}(40 \mathrm{~dB}, 60 \mathrm{~dB}$ 共に) 及び $60 \mathrm{~dB}$ にて 測定した 600〜850 cps でも非切断音の場合より大きな 後達音增強を必要上した．しかし，600〜850cps (40dB) では切断による效果は殆んど見られなかつた。

各検查音を通して切断回数と $\mathrm{T}$ vs I との関係は判然 としなかつた，持秸音による T vs I の実験で検査音の 大きさが 60dB であるより 40dB である 万が T vs I ratio が小であつたことは，切断音による实鈳でも同じ ですつた。

また，非切断音による㝬験中に，時間差があまり大き くなつた場合や，检查音があまり大きくなつた時に，一 つの音像を結ばす゚に2つの音に分離して聞える現象があ つたが，検查音を切断することによりその現象が消失 し，更に切䉼音による音像は非切断音による音像に比べ て非掌に臂明で，軌跡の認知も明確であつた。

\section{$\mathbf{v}$ 総括並ひに考按}

i. 実験淩䈯の特長

方向感成立機序に閶係招因子は，強度差，時間差，
位相差，音色，空間知覚など 数多くあげられているク か゚，音源から两耳へ到達するに要する時間差と两耳間の 音の強度差が最る大きな役割を占めると考えられる。

この 2 因子についての検査法のらち，空間に設置した 2 つのスピーカーを利用する，いわゆる diotic な方法 によつては, 到達時間差を変えよらとすれば強度差の変 化や遮蔽現象や干涉作用などの諸因子が加わり，現象を みるには與味灌いが，強度差と時間差の役割を単独に撿 陆することは不可能である. 万向感成立機客を究める目 的には時間差と強度差を切離してつくりだすことが必要 である。

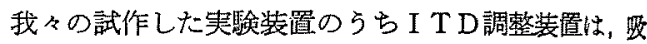
音楔を利用して定常波ができるる予防し、マイクロ

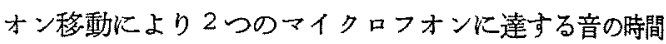
差をつくつても両マイクロフオンに拈ける音の強さの差 は標めて小さいように工夫され，300cps から 2000cps までの周波数带では，それを僅か１万至 $2 \mathrm{~dB}$ 以内此 めることがでさる，更に同じＩＴＤ調整装置を2つ䜅 け，接続機械を2チャンネルにしてあるため，一側2 重の音を入れることができる．このことは強度差と時間 差の関係を検討するうえに非常に便利で，ある角度に音 像を倔倚させるに要する時間差と強度差を別個に測定す ることを可能にする.今回の T vs I の実験結果と比䕀 検討することにより時間差と強度差の関係を異つた 20 の観点から検討することができる（後述）

ii. 実験方法とその原理に関する考按

両耳間の音の到達時間差と強度差の関係を調べる方法 に㤌 2 つの loudspeaker を利朋する diotic な方法 ${ }^{10}$ の他に，earphone を使用する dichoticな方法がある ことは先に述べたが，後者には更に2つの方法が考えら れる。

第一11) 12）の方法は時間差によつて偏倚させた音像を 正中に 戾すに要する後達音の增強を測定するすので (centering technique)，今回我々が用いた方法がそれて ある、第二の方法 ${ }^{13}$ は，強度差によつて㾫倚させた音 像に時間差によつて偏倚させたもら一つの音像を重和合 せる万法である (matching technique)，前者はある時 間差を与えた条件の下で強度差を与えて音像を正中に民 寸头跧であり，音像の位置は強度差と時間差の函数で る、これに反して後者は音像の位置を時間差のみ，また は強度差のみによつて規定しようとするもので，この点 において 2 万法は相異るものである。

Matzker ${ }^{14)}$ は方向感成立機序を，脳幹部に批いて先 
行音が後達音の一部を抑制し，それが loudness の差と して大脳皮質へ投影されることによると考えているが，

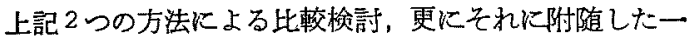
連の実駼を連立方程式の如く組合せることによつて，脳 幹部に拉ける抑制機構を究明することも期待できる。

例えば centering technique で，予め与える時間差 を $\Delta \mathrm{t}$ とし，これによつてできた音像を正中位に戻すに 要した胎度盖を $\Delta \mathrm{i}_{1}$ とする. 次いで matching tech-

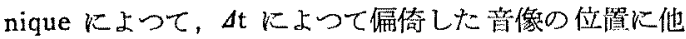
の音像を重加命せるに姴した㤝度差 $\Delta \mathrm{i}_{2}$ を測定する。

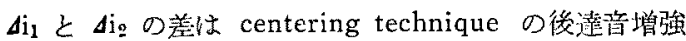
分に対する $\Delta \mathrm{t}$ 亿よる抑制と考兄られる。

今回の实験は centering technique に限つたが，こ の種の实験にはかなりの知性と練習を必要とする。測定 に当つては疲労現象や暗示による心理的影響を厳しく避 けることが必要である.

また，被检者の“きき耳”汇よる正中軸の偏倚がある ことにも留意して earphone を左右交换して 再度測定 することも必要である．正中位を明確にしておくには一 つの音像を正中に結ばせてめじるしにするのも一法で ある．それには切断音を使用する場合には，rise and decay time を非常に短くして切断の瞬間に生ずる click が必ず正中位に，乙か必明膫に音像を結ぶことを利用す るのが便利である。

初めて音像の移動が認められる時間差（時間差最小認 知域値 just noticeable difference in time) 仿 20 30 才代で約 $1.5 \mathrm{~cm}$ であり，年令之共に增大寸る偭向があ るのか，その差を封開差域值の差として表わすには差 が僅少であるために困䧼が多い，ところが centering

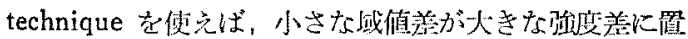

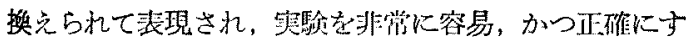

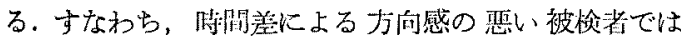
centering technique で僅かな後達音の增強で音像を正 中に厌すことか゚できる．正常者に比べて明らかに差が認 められ，これにより正党者と洔間羑力向感障害者とが区 別できる。もし一般に言われる如く，洔䦌差による力向 感师枢に打訬る相互作用 (interaction) のみに上るる のであるならば，中枢障畵者を選び出す大きな手段とな ることが期待される。

iii. 時閒差及び強度差の範团々音像の性質 diotic な实験で㥩像が頭の外飞できる（localiza-

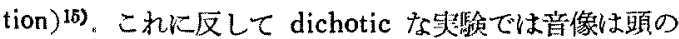
中に生じて (lateralization) ${ }^{16)}$ ，その音像の軌跡は頭頂
部ないしは少し後頭部寄りに，頭の外周にそつて大略円 形を描き，雨耳側に执いて嚾かながら頭外に出る感があ る．時間盖または強度差を変化させると音像の斬跡は明 確に認知学礼るが，音の強さがあまり大きくなると音像 は拨がりを增して明確さが減少与る。

さて，音像の偏倚を認めらる最小の洔間盖及び強度羑 と，音像が完全に外側に蒿つてしまら㭙間差と強度善は どのような值であるらか。

A.W. Mill 17) によると SL 50dB の㧎断純音を検查 音に使用し，時間差がない場合に強度差の最小琶知域值

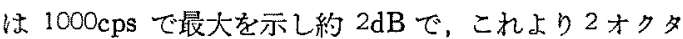
ーブ上及び下の 周波数では1dB に下つた.180度の位 相差を与えると $1000 \mathrm{cps}$ で最大とはならなかつた。 た半オクターブ幅の騒音を使用すると，位相差が 0 及び 180 度のいずれの場合でる $1000 \mathrm{cps}$ で最大とならず。 click を使用した実験では位相差を与学ると，位相差を 与之ない場合の域值の2倍であつた. Small, Bacon \& Fozard 18) はオクターブ幅の band-noise を使用し， 低，中，高周波数带の 強度差の 最小認知域値を测定し た。高周波数带（4080 8160 cps）特よび中周波数带 (1040 2080cps) の最小認知域值は低周波数帯（127〜 $255 \mathrm{cps}$ ) の最小認知域值より小さく，広周波数帯の最小 認知域値は更にそれ上り小さからたと報告している。

すなわわ，正中部に音像を結ぱせた場合の方が強度差 による音像の偏倚が容易に認知されて，最小認知域値は 音の種類，周波数に関係する，我々の奏唋では時間差な しで 600 850cps の band-noise で約 $2 \mathrm{~dB}$ で音像の移 動琶めた。

さらに我々は強度差がない条件下で㭙間差を与克て时 開差の最小認知域值を測定したが，楽音，言語音，半オ クタープ幅の band-noise は $1.5 \mathrm{~cm}$ の位相美によつて 音像の偏倚を認め，純部ではこれに少ることを知つた。

文献的にこ机をみると，Röser ${ }^{199}$ 江 $800 \mathrm{~Hz}$ て最小 の位相差域值を示し周波数が增加与ると共任位相差域值 る增加すると郝告した，Matzker 5)の实駼によれい゙，

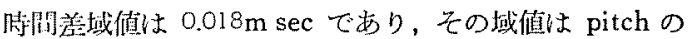

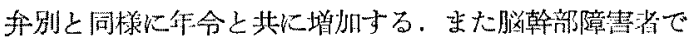
は著しい域值の上苌があり，大脳半球に病㮺をもつ患者

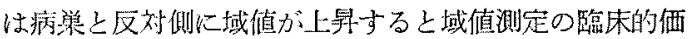
值にまで言及している。

一方，音像を完全に外側入扁倚させるに要する時間美 及び㧧度差について，同じく Matzker ${ }^{5)}$ は $0.648 \mathrm{msec}$, $25 \mathrm{~dB}$ なる值を提示し， $25 \mathrm{~dB}$ の強度差は时間差によつ 
ては到底補うことができないこと，および時間差で補ら

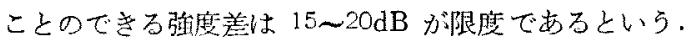

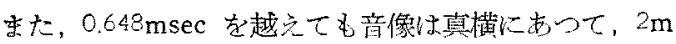
sec を越えると音は両側に分離して聞无る。これは Jungert が㵋定した中枢㳳覚路の refraction time $か 52 \mathrm{~m}$

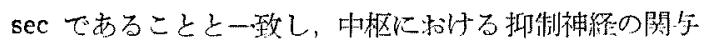
を暗示するるのであると説明している，Blodgett et al

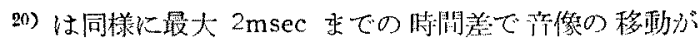

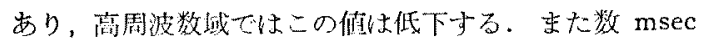
までは音像为 impact であるが，それ以上になると

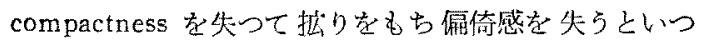
ている。

我々の实貿炕和いては，600 850cps $の$ band-noise で $0.6 \mathrm{msec} \sim \mathrm{msec}$ の㭙間差，約 $30 \mathrm{~dB}$ の強暨差で真

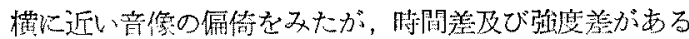

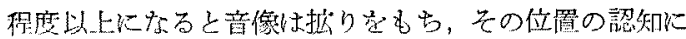
は遠近感が加かることを知つた。雪に，低曋域では 0.6

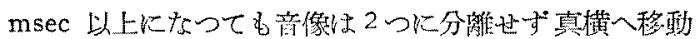
することが諗知されたのに反し，高音域では $0.6 \mathrm{msec}$

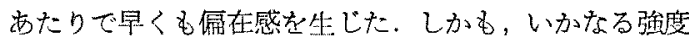
差，時間差によつても完全に真横の位置にまで音像を移 動させることはできなかつた。これは大きな時間差及び 胎度羕のために音像が幾らかの推がりをるち，しかも众 查音がある幅の周波数を含んでいるために，音像の位罢

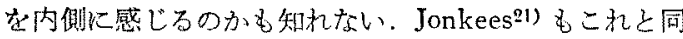
様のこ之安 diotic な东駼で颜めて抢り，一般に开面て

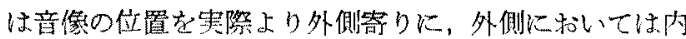
側寄りに感じる傾向があることを指摘している。

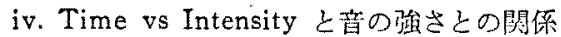

上記の如く強大音側に，または早く到管した音の側に ごきた音像は，音像の反対側の音を早く聞かせたり，增 強してやることによつて正中位に辱すことができる。 のよらな時間差と強度差との䦛佰，才なわち T vs I を dichotic に調べる力法に2つあることは先に述べた。 今 回行つた centering techniqueによつて純音，䮎空は

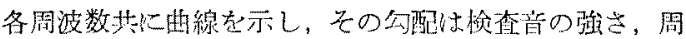

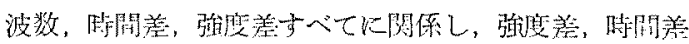

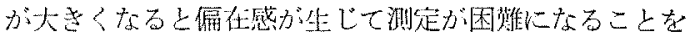
知告。

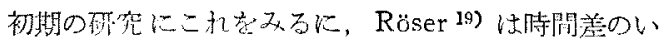

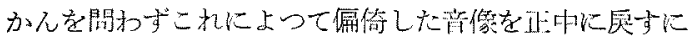

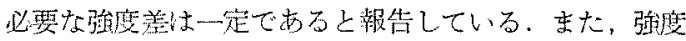

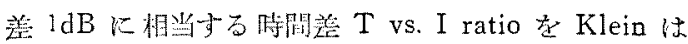

$0.13 \mathrm{msec} / \mathrm{dB}$ (click 便用), Banister は 0.25 0.09m sec/dB (絈) , Schaxby \& Gage it $0.13 \mathrm{msec} / \mathrm{dB}$, Christian \& Victor it $100 \sim 150 \mu \mathrm{sec} / \mathrm{dB}$ と壀告 閏差と強度美の間には直線的関係があると哥つてい 3. 11)

一j, David, Goodmann \& Bergeijik 12) \&よひ Deatherage \& Hirsh ${ }^{11)}$ は域䛧近くの音の大きさでは $100 \mathrm{msec} / \mathrm{dB}$ 越え石が，強い商ではそれより小とり T的 I ratio は检查境の㤝さにより異るとし, low level の click $\odot \mathrm{T}$ vs I ratio 4 high level $\infty$ click $\emptyset$

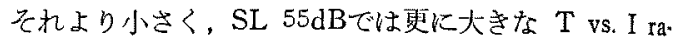
tio を報告している. Mouschegian \& Jeffress ${ }^{13)} こ$ れを支持する研究を発表した。更に，Whitworth \&

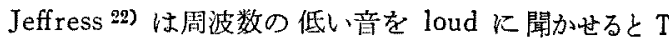
vs. I ratioは最小となり， click を弱く聞かせると最

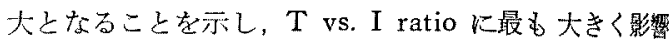
するのは険查音の性盾と強さであると結論した。

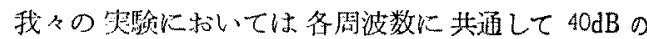
T vs. I ratio は $20 \mathrm{~dB}$ のそれより小さい值を示してい るが，60dB とい5大きな検查音では却つて大きくな た。この理由杂推測してみると，60dB の場合性弦大普 を聞かせることになり痏学及び順応の要素が加わること と音像に抬りや笰在感が生じ测定に困難さが加わること などが溊係しているのではないかと考えられる。

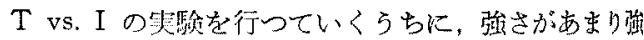

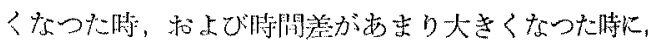

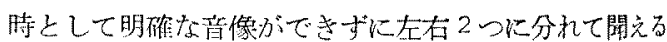
現象が楒められた。

これに似た現像は Banister, Deatherage ${ }^{\text {(3) }}$ 执よび Whitworth \& Jeffress ${ }^{22}$ ) の諭文にも見られる. Banis.

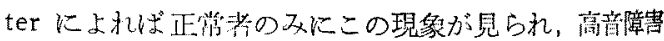
のある被榆諸に浔認るられなからた，分離して聞点る2

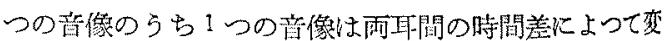
化するわ口时間差によつて生ずるとして“ time image”

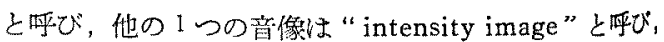

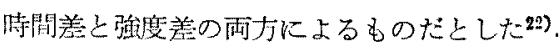

この2つの音像について我々は先式交叒現象 (cross

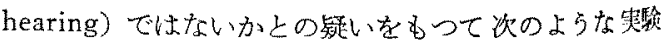
を行つた。すなわち，先才゙正中位に 1 つ音像を $45 \mathrm{~dB}$

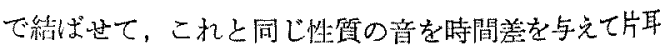
に入れると，初めに筜像をつくつた音の強さと後から閶 かせた著の强さの盖が $5 \mathrm{~dB}$ 以内になつたとき初めて第

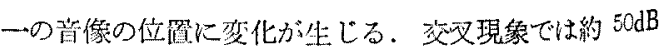


以上の減弱が持こることを落えあわせると，音像と区対 側に $80 \mathrm{~dB}$ の音を聞かせてる初めにできた音像の位监

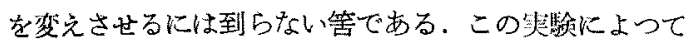
険查音が大きい場合湆像が分離して雨側に聞える現象 は交叉現象によるものでないことが判つたが，その成因 についての確かな理論は持つていない，しかし検植㳻が 非常に大きい場合にのみ生ずること，检查音を率断音に 変えることによつてこの現象がなくなることから考えて 疲労現象に関係がある之推定される。亦た弱、音や中等 度の強さの音では外有毛細胞の働きが主体をなし，强大 音の場合には内有毛細胞の㗢きがこれに加かり，しかも 内有毛細胞は外有毛細胞に比べて方问暿に関保する因子 は少なく，かつ外有毛細胒の方感とは異種のものでは

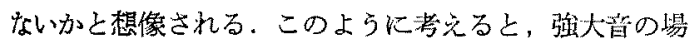
合の T vs I ratio が大きくなることや，强さによるケ 向感と時間差による方向感が別ものではないかといら疑 間 19)につて考えるときに好都合である。

v. Time vs. Intensity 之偽波数の関保

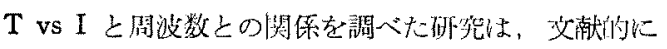
は Mouschegian \& Jeffress ${ }^{19)}$ にみるのみである。そ れも matching technique によるものであつて, cen tering technique Kよるものは見当らない.

我々は centering technique によつて 600 550cps の band-noise の T vs I ratio が最小で, 時閂差の占 める役制が最も大きいことを知つた. Mouschegian \& Jeffress ${ }^{13)}$ matching technique により $500 \mathrm{cps}$,

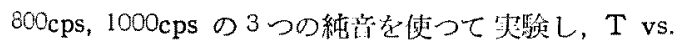
I ratio $4500 \mathrm{cps}$ で $1.8 \mu \mathrm{sec} / \mathrm{dB}, 800 \mathrm{cps}$ で $6 \mu \mathrm{sec} / \mathrm{dB}$, $1000 \mathrm{cps}$ で $4 \mu \mathrm{sec} / \mathrm{dB}$ という值を報告している.

ここで文献的に位相差最小認知域値を調べた実蜸上比 較娭討してみ上う. Kietz ${ }^{24)}$ は localization の傤能の 正確さを時間美最小認知域俌で愫示せ几とした，被の䒠 験によると最小認知域值は $800 \mathrm{cps} て ゙$ 熶小で，これより

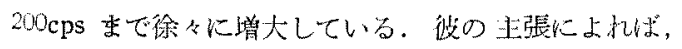
こ机は音波の slopeによつて說明されている. $800 \mathrm{cps}$ の音波の slopeは $250 \mathrm{cps}$ のそれの4偣であり，当つ 々 slope の急なもの佂更に localization が正確で好 5. 従つて abrupt complex noise が最良であるらと 于想している.Zwislochi \& Feldmann ${ }^{25)}$ の報告によ つても最小認知成值小、800 cps もたりが最小であり，

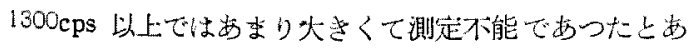
จ.

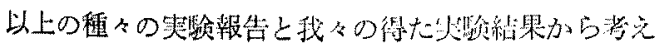

て，万向感において最も時間差が大きな役割を果してい ると考党られる閣波数は $800 \mathrm{cps}$ 附近である。

では，力问感の成立する周沿数带はどの上うな範罒に あるだららか. Matzker ${ }^{14)}$ は $800 \mathrm{~Hz}$ が最良であり，

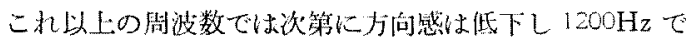
上らやく保大れているとい5，Röser ${ }^{19)}$ ( $1100 \mathrm{~Hz}$ 以 上の純音怯打问感が成立しない上し，Zwislochi \&

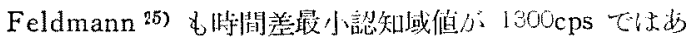
まり大きくて測定不能であつたと方问柋成立桠能の消头 を暗示している，また，Stevens \& Newman ${ }^{26)}$ は, 純音の方问感は阔波数によつて非常に美があり，1000 cps 以下は良好で交るが 2000 4000 cps は殆儿どなく， $6000 \mathrm{cps}$ 以上飞なると再じ方向感が現加れるといってい る.

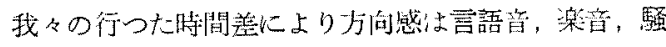
音がよく切断純音がこれに次ぎ，純音が最も思いしか

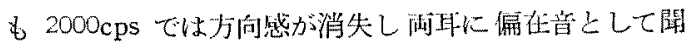

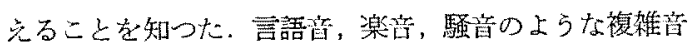
の方问堅がよいことは，Whitworth \& Jeffress ${ }^{22)}$ 及 び Firestone 27) の言うように高音と低音を其に持つて いて时間差に上る方向感要素と強度差による方向骶要素 を適当に艺なえているからであると説明できる、1000 cps 以上の純音の時間差に上る方向感が急に低下し，あ るいは消失する原因としては，神释の不応期上関連して 刺激音が完全な time information をなさないことが第

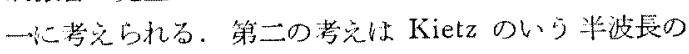

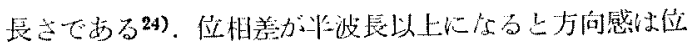

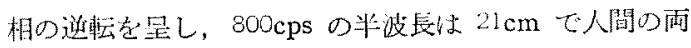
耳間の距離 (Mayer による) と同じであるから $800 \mathrm{cps}$ 以上になると位相の近枟のために力问感の低下なたは消 失をきたすと解釈したい。

vi. 㛟直音切断に上\% Time vs. Intensity への影䇾

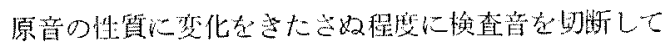

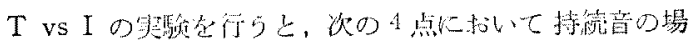

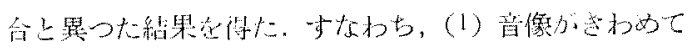

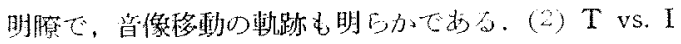

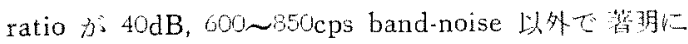

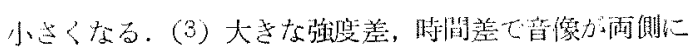

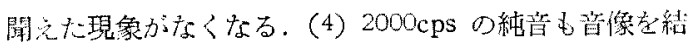
ら゙よらになる。

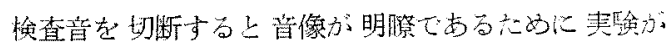

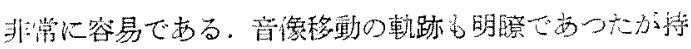

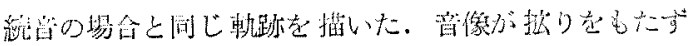




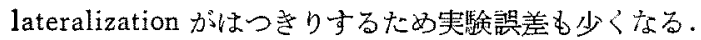
$40 \mathrm{~dB}, 600 \sim 850 \mathrm{cps}$ band-noise を検査音として时間差 を $15 \mathrm{~cm}$ とした場合の標準偏差が $2.2 \mathrm{~dB}$ 以下で，持緛 音の場合が3.3dB であつたことと比較して多るとき，

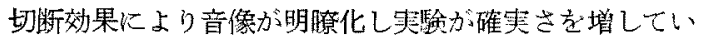
各こ上か；容易飞推测される。

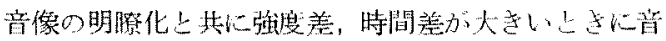

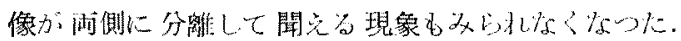

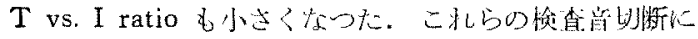

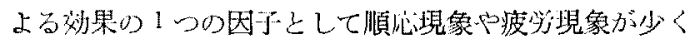

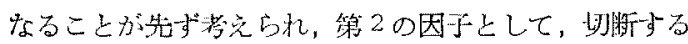

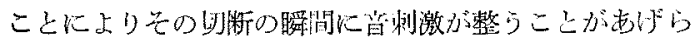
机石。

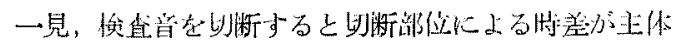
となつて，电ともとの到犊特間差と别の性質を带びてく

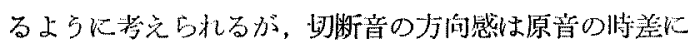

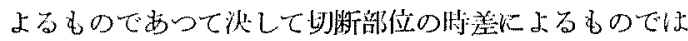

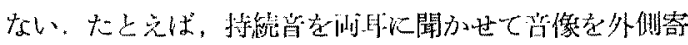
りに絬ばせて和き，この持続音を electroswitchで切断

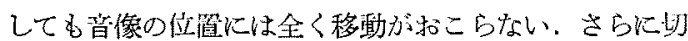
断它の rise and decay time t短々 $10 \mathrm{msec}$ 以下に与 ると甽断の瞬間に click が生じるが，この clickによ る沓像は正中に結ばれて原音の音像は全く移動しない。

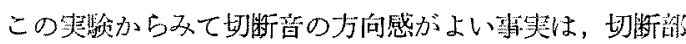
位に上る协果ではなく，切断するためにできた何らかの 效果によるものと考之られる。

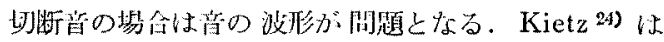

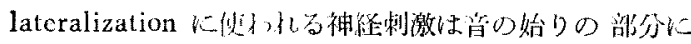

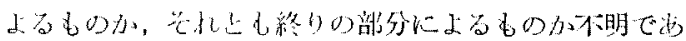

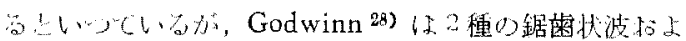

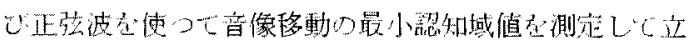

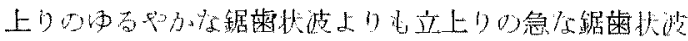

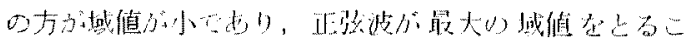

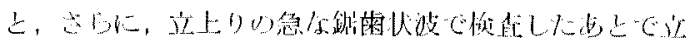

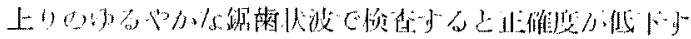
る心

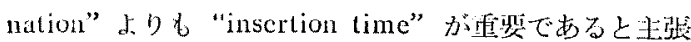
し.Cい.る.

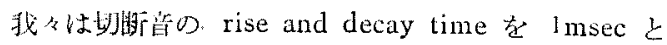
$25 \mathrm{msec}$ のつの埸合に分けて比較したが，いー゙れの璂 合でも測定值に大差がなかつた。 また，切断回数を短秒 0.2 回，1回，2回，4回，10回，20回と変觉て 测定し てみたが有意の因は思せなかつた。

\section{VI 結 諭}

1. 音の聞えの方向感において，雨耳に入る音の時間 差と強度差の関係を測定研究するのに理想的な検査機雄 ぞ試作し，その機構について解説した。

2. 両耳に入る音の時間差によつて生ずる方向感山楽

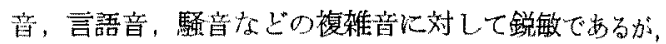

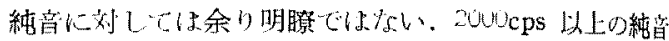

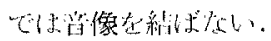

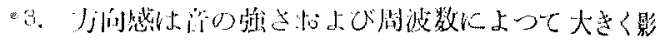
瑟さ水方。

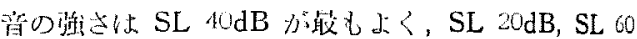
$\mathrm{dB}$ はこれり誃る。

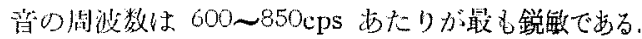

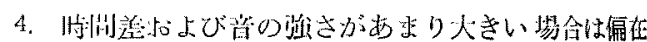
愁子注しる。

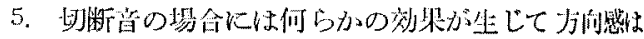
銧酷亡\%万。

\section{VII 文献}

1) Jerger, J.: Observation on Auditory Behavior in Lesions of the Central (Auditory Pathways. A. M.A. Archiv. Otolaryng. 71: 797, 1960. 2) Groen, J.J. and Hellema, A.C. M.: Binaural Speech Au. diometry. Acta Oto-laryng. 52: 397, 1960. 3) Matzker, J.: Ein Binauraler Hörsynthese-Test zum Nachweis Zerebraler Hörstörungen. Georg Thieme Verlag, Stuttgart 1958. 4) Bocca, E.: Binaural Hearing; Another Approach. Laryngoscope 65:1164, 1955. 5) Malzker. J.u. Welker, H: Die Prüfunt des Richtungshürens zum Nachweis und zur topischen Diagnostik von Hirnerkrankungen. Z. Laryng 60: $27,195 \%$ o) Jonkees, L.B.W. and Vecr, R.A.V.D.: Directional Hearing Capacity in Hearing Disorders. Acta Oto-laryng. 48: 465, 1957. 7) Sunckez-Longo, L.P., Forster, F.M. and Auth, T.L.: A Clinical Test for Sound Localization and its Applications. Neurology 7:655, 1957. 8) Sanchex. Longo, L.P. and Forster, F.M.: Clinical Significance of lmpairment of Sound Localization. Neurology 8 :

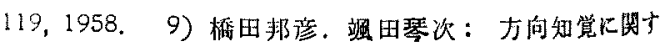
る主要策綨，昭 16.10$)$ Sandel, T.T., Teas, D.C., Feddersen, W.F. and Jeffress, J.A.: Localization of Sound from Single and Paired Sources. J. Acoust. Soc. Am. $27: 842,1955$. 11) Deatherage, B.H. and 
Hirsh, I.J.: Auditory Localization of Clicks. J. Acoust. Soc. Am. 31 : 486, 1959. 12) David, E.E., Newman, J., Guttman and Bergeijk, W.A.: Binaural Interaction of High-Frequency Complex Stimuli. J. Acoust. Soc. Am. 31: 774, 1959. 13) Moushegian, G. and Jeffress, L.A.: Role of Interaural Time and Intensity Difference in the Lateralization of Low Frequency Tones. J. Acoust. Soc. Am. $31:$ 1441, 1959. 14) Matzker, J.: Versuch einer Erklärung des Richtungshörens auf Grund feinster Zeitunterschiedsregistrierungen. Acta Otolaryng. 49:483, 1958. 15) Kilagawa, S. \& Shintaku Y.: Direction Perception and Subjective Auditory Direction Line. Acta Oto-laryng. $47: 431,1957.16)$ Jeffress, L. A. and Taylor, R. W.: Lateralization vs. Localization. J. Acoust. Soc. Am. 33: 482, 1961. 17) Mills, A.W.: Thresholds for Interaural Difference in Intensity. J. Acoust. Soc. Am. 31: 830, 1959. 18) Small, M., Bacon, W.E. and Fozard, J.L.: Intensive Differential Thresholds for Octave Band Noise. J. Acoust. Soc. Am. 31: 128, 1959. 19) Röser, D.: Die zentralen Vorgänge beim Richtungshören. Arch. Ohr.-Nas.- u. Kehlk.-Heilk. 177 : 57, 1960. 20) Blodgett, H.C., Wilhanks, W. A. and Jeffress, L.: Effect of Large Interaural Time Differences upon the Judgment of Sidedness. J. Acoust. Soc. Am. 28: 639, 1956.21 ) Jonkees, L.B.W. and Veer, R.A.: Further Investigations into a Peculiarity of Normal Directional Hearing. Acta Oto-laryng. 49: 47, 1958. 22) Whitworth, R. H. and Jeffress, L. A.: Time vs. Intensity in the Localization of Tones. J. Acoust. Soc. Am. 33 : 925, 1961. 20) Deatherage, B. H.: Binaural Interaction of Clicks of Different Frequency Content. J. Acoust. Soc. Am. 33: 139, 1961. 24) Kietz, H.: Neue Vorstellungen in der Theorie des Hörens. Z. Laryng. 36:241, 1957, 25) Zwislocki, J. and Feldman, R.S.: Just Noticeable Differences in the Dichotic Phase. J. Acoust. Soc. Am. 28: 860, 1956. 26) Slevens, S.S. and Newman, E.B.: The Localization of (Actual Sources of Sound. Am. J. Psychol. 48: 297, 1936. 27) Firestone, C.: Binaural Localization of Pure Tones. J. Acoust. Soc. Am. 2:271, 1930. 28) Godwinn, R.W.: Clinical Testing for Sound Localization. Ann. Otol. 10:976, 1961.

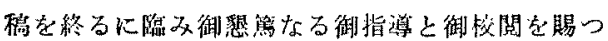

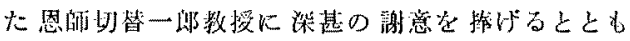

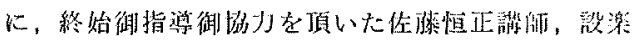

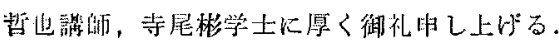

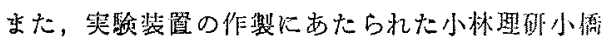

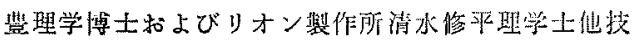
術第一深の諸士に深く感謝の意を表与

本砄究は炤和 36 年度及び 37 年度の文部省科学試

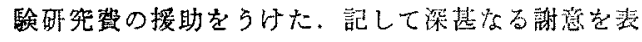
する。

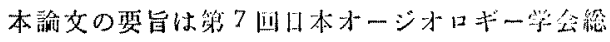
会に蛙いて発表した。

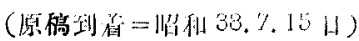

